\title{
Diallel analysis of fruit set in Hevea brasiliensis Muell. Arg.
}

\author{
Kenneth O. Omokhafe, Frederick A. Akpobome and Ibrahim Nasiru \\ Department of Crop Improvement and Biotechnology, Rubber Research Institute of Nigeria, \\ Benin City, Nigeria.
}

\begin{abstract}
The clonal and inter-clonal combining ability of fruit set in a Hevea brasiliensis four-parent diallel mating was evaluated using a randomized complete block experimental design with three replicates. Twelve main and reciprocal crosses were hand pollinated and percentage fruit set was recorded. The raw data were subjected to an arc-sine transformation for analysis of variance, and general and specific combining ability. There was significant variation of each of fruit set for the various crosses, general combining ability and reciprocal effect. The breeding implications of these results are also discussed.
\end{abstract}

Key words: fruit set, Hevea, combining ability.

Received: May 16, 2006; Accepted: November 6, 2006.

Hand pollination is a vital means of combining genes of two or more varieties to produce progenies, the evaluation and selection of which leads to the recommendation of new varieties that have gene combinations superior to the parent population. This procedure has enhanced the genetic improvement of latex yield from the Pará rubber tree (Hevea brasiliensis) from the 300 to $400 \mathrm{~kg} \mathrm{ha}^{-1}$ for the original Wickham germplasm pool to 900 to $1600 \mathrm{~kg} \mathrm{ha}^{-1}$ for first generation hybrid vegetative clones and 2000 to $3500 \mathrm{~kg}$ ha $\mathrm{y}^{-1}$ for second group hybrid vegetative clones (Omokhafe and Nasiru 2005).

One of the limitations to the field success of hand pollination of monoecious $\mathrm{H}$. brasiliensis is that the fruit set is often as low as $5 \%$, rarely exceeds $10 \%$ (Priyadarshan and Clement-Demange, 2004) and pollination success in open pollination is in most cases even less than $2 \%$ (Hamzah et al. 2002). Olapade and Omokhafe (1990) reported significant clonal variation for $H$. brasiliensis fruit set, suggesting that genetic factors influence the incidence of fruit set. One of the methods to produce more hybrid progeny for evaluation is embryo rescue after fruit set (Carron et al. 1989), with the success of in vitro embryo rescue therefore depending on fruit set. Genetic improvement for fruit set requires knowledge of the level of gene action.

This study was conducted to investigate the combining ability of fruit set in $\mathrm{H}$. brasiliensis.

Send correspondence to Kenneth O. Omokhafe. Department of Crop Improvement and Biotechnology, Rubber Research Institute of Nigeria, P.M.B. 1049, 300001 Benin City, Nigeria. E-mail: kenomokhafe2001@yahoo.com.
A four-parent diallel mating design was developed for hand pollination in one-way and reciprocal crosses at the main station of the Rubber Research Institute of Nigeria, Iyanomo, Benin City, Nigeria. The test-clones were PB 5/51 and RRIM 600 from Malaysia, PR 107 of Indonesian origin and NIG 800 developed in Nigeria. Clone PB5/51 has parentage of $\mathrm{PB} 5 / 56 \times \mathrm{PB} 24$ while the parentage of RRIM 600 is Tjir $1 \times$ PB 86 . Clone PR 107 is from primary selection and the parentage of NIG 800 is RRIM $501 \mathrm{x}$ Har 1.

A randomized complete block experimental design with three replicates was applied. Twelve crosses resulting from the one-way and reciprocals were carried out with 100 to 120 pollinated flowers per replicate. Hand pollination of H. brasiliensis was carried out in March 2005 between 0800 and $1100 \mathrm{~h}$ local time by taking pollen from mature male flowers of the male parent clones to pollinate the mature female flowers of the female parent clones before the stigma lobes were exposed. For each flower, forceps were surface-sterilized by swabbing with cotton wool moistened with $70 \%(\mathrm{v} / \mathrm{v})$ ethanol and used to open up the petals before natural anthesis. As soon as pollen grains of the chosen male parent were introduced to the stigma lobes, the column of petals was sealed with cotton wool moistened with a drop of latex to hold it in place and hence exclude undesirable pollen. For each inflorescence, all unpollinated female flowers and male flowers were excised to avoid self-pollination and minimize nutrient competition with the pollinated female flowers. Fruit set was recorded in June 2005. 
Percentage fruit set per replicate was calculated and transformed using an arc-sine transformation as recommended by Omokhafe (2001) followed by analysis of variance (ANOVAR) and diallel analysis. In the diallel analysis, the Griffing Method 3 approach, which uses F1 and reciprocals, was applied and combining ability, as fixed effects, were calculated as described by Singh and Chaudhary (1985). The effects of general and specific combining ability (GCA and SCA respectively) and reciprocals were also calculated.

There was significant variation in fruit set across the twelve crosses, the two groups of crosses (main and reciprocals), families of crosses, and the interaction between families and groups of crosses (Table 1). The significant effect of clones and the interaction between clonal families and groups of crosses suggest the combination of gene action and environment on the incidence of fruit set in $H$. brasiliensis.

There was higher fruit set $(7.14 \%)$ in the main crosses than in the reciprocals $(6.42 \%)$ and three families had a higher average fruit set than the $6.78 \%$ overall mean (Table 2); the overall mean being comparable to the range of fruit set in hand pollination of $H$. brasiliensis reported by Olapade and Omokhafe (1990) who also reported significant clonal variation and interaction effects.

Variance due to GCA (0.09) was significant, with a GCA to SCA variance ratio of 9:1 (Table 1). This is in agreement with the work of Tuy et al. (2005), who reported the relative advantage of GCA over SCA for $H$. brasiliensis juvenile latex yield and girth. The results of this study indicate that several of the test-clones had a high propensity to pass fruit set genes to the next generation among the crosses and since GCA estimates additive genetic variance and SCA non-additive genetic variance, the predominance of GCA effects suggests that genetic control of fruit set in the $H$. brasiliensis populations studied was mainly conditioned by additive gene effects. Clones with high fruit set in crosses and high clonal GCA will likely offer higher pollination success than the population mean in a wide range of crosses. The highest GCA values in our study were for

Table 1 - Analysis of variance mean square values for fruit set in Hevea brasiliensis. Twelve crosses, six families of main and reciprocal crosses and combining ability for a diallel mating design.

\begin{tabular}{|c|c|c|c|c|c|c|c|}
\hline \multirow{3}{*}{$\begin{array}{l}\text { Source of } \\
\text { variation }\end{array}$} & \multicolumn{2}{|c|}{ Twelve crosses } & \multicolumn{3}{|c|}{ Six families of main and reciprocal crosses } & \multicolumn{2}{|c|}{ Combining ability } \\
\hline & \multirow[b]{2}{*}{$\mathrm{df}$} & \multirow[b]{2}{*}{ Mean square } & \multirow[b]{2}{*}{$\mathrm{df}$} & \multicolumn{2}{|c|}{ Mean square } & \multirow[b]{2}{*}{ Mean square } & \multirow[b]{2}{*}{ Variance } \\
\hline & & & & Main & Reciprocal & & \\
\hline Replicate & 2 & $0.99 *$ & 2 & 0.39 & 0.61 & - & - \\
\hline Crosses & 11 & $2.68 *$ & 5 & $3.67^{*}$ & $1.31^{*}$ & - & - \\
\hline Group (G) & 1 & $1.52 *$ & - & - & - & - & - \\
\hline Family $(\mathrm{F})$ & 5 & $2.39 *$ & - & - & - & - & - \\
\hline Gx F & 5 & $3.00^{*}$ & - & - & - & - & - \\
\hline GCA & - & - & - & - & - & $0.39 *$ & 0.09 \\
\hline SCA & - & - & - & - & - & 0.06 & 0.01 \\
\hline Reciprocals & - & - & - & - & - & $1.31^{*}$ & 0.63 \\
\hline Error & 22 & 0.14 & 10 & 0.41 & 0.20 & 0.05 & - \\
\hline
\end{tabular}

*Significant at $\mathrm{p}=0.01(\mathrm{~F}-$ test $)$; General and specific combining ability variance ratio $=9: 1 ;-$ : not applicable; $\mathrm{df}=$ degrees of freedom.

Table 2 - Fruit set (\%), family mean (\%), reciprocal effect (RE), general and specific combining ability (GCA and SCA) for a four-parent diallel mating design in Hevea brasiliensis. Numbers in parenthesis represent rank.

\begin{tabular}{|c|c|c|c|c|c|c|c|c|}
\hline \multicolumn{2}{|l|}{ Main crosses } & \multicolumn{2}{|c|}{ Reciprocal crosses } & \multirow[b]{2}{*}{ Family mean } & \multirow[b]{2}{*}{$\mathrm{RE}$} & \multirow[b]{2}{*}{ SCA } & \multicolumn{2}{|c|}{ Clonal GCA } \\
\hline Cross & Fruit set & Cross & Fruit set & & & & Genotype & GCA \\
\hline PB 5/51 x RRIM 600 & $4.61(11)$ & RRIM 600 x PB 5/51 & $8.52(2)$ & $6.56(5)$ & $1.03(2)$ & $-0.06(4)$ & PB 5/51 & $-0.38(4)$ \\
\hline PB 5/51 x NIG 800 & $6.00(9)$ & NIG $800 \times$ PB 5/51 & $5.81(10)$ & $5.91(6)$ & $0.02(6)$ & $-0.08(5)$ & RRIM 600 & $0.16(2)$ \\
\hline PB 5/51 x PR 107 & $6.25(7)$ & PR107 x PB 5/51 & $7.02(5)$ & $6.64(4)$ & $0.25(5)$ & $0.14(1)$ & NIG 800 & $0.02(3)$ \\
\hline RRIM 600 x NIG 800 & $10.00(1)$ & NIG 800 x RRIM 600 & $4.58(12)$ & $7.29(1)$ & $1.54(1)$ & $0.13(2)$ & PR 107 & $0.20(1)$ \\
\hline RRIM $600 \times$ PR 107 & $8.08(3)$ & PR 107 x RRIM 600 & $6.44(6)$ & $7.26(2)$ & $0.45(4)$ & $-0.09(6)$ & - & - \\
\hline NIG 800 x PR 107 & $7.87(4)$ & PR 107 x NIG 800 & $6.13(8)$ & $7.00(3)$ & $0.50(3)$ & $-0.05(3)$ & - & - \\
\hline Mean & 7.14 & - & 6.42 & 6.78 & - & - & - & - \\
\hline
\end{tabular}

-: not applicable. 
clones PR $107(\mathrm{GCA}=0.20)$ and RRIM $600(\mathrm{GCA}=0.16)$, which are thus preferred parental clones for genetic improvement of fruit set in Hevea brasiliensis (Table 2). Relatively high latex-yield GCA values for PR 107 have previously been reported by Olapade (1991).

In addition to the significant difference between the main and reciprocal crosses, the reciprocal effect was significant with a variance component of 0.63 (Table 1). This suggests the involvement of cytoplasmic genes in the control of fruit set, indicating that the maternal genetic background had a significant impact on the incidence of fruit set. The highest reciprocal effect (1.54) was obtained with RRIM $600 \times$ NIG 800, indicating that the maternal (cytoplasmic) background of RRIM $600 \mathrm{had}$ a positive influence on fruit set (Table 2). In the three instances in which RRIM 600 was the female parent, fruit set ranked first to third while fruit set in two reciprocal crosses in which RRIM 600 was the male parent ranked low at the eleventh and twelfth positions (Table 2). The contrasting performance of RRIM 600 as a female parent compared to its pollination success as a male parent is a good example of cytoplasmic effects on fruit set.

Regarding SCA values, the cross of PB 5/51 x PR 107 (fruit set $=6.25 \%$ ) set with its reciprocal PR $107 \times$ PB 5/51 (fruit set $=7.02 \%$ ) ranked first in SCA value $(0.14)$, the family fruit set value being $6.64 \%$ (Table 2). This suggests that despite the significant reciprocal and maternal effects, few crosses will be relatively consistent for fruit set in both main and reciprocal crosses.

In conclusion, there was significant variation for fruit set in $H$. brasiliensis and a high level of general combining ability, with prospects of genetic improvement of low fruit set. There was evidence of cytoplasmic gene effects on the incidence of fruit set. Suitable experimental designs will be developed in further studies to isolate cytoplasmic gene effects from the estimate of additive genetic variance.

\section{Acknowledgments}

The authors are grateful to the Executive Director, Rubber Research Institute of Nigeria for the support of this study. We are also grateful to Dr. B.A. Nwankwo, a consultant to the Tissue Culture Cooperation Project, for his technical assistance. The field assistance of Mr. E. Aifuwa is hereby acknowledged.

\section{References}

Carron MP, Enjalric F, Lardet L and Deschamps A (1989) Rubber (Hevea brasiliensis Muell. Arg.). In: Bajaj YPS (ed) Trees II: Biotechnology in Agriculture and Forestry. SpringlerVerlag, Berlin, pp 222-245.

Hamzah S, Chan JL and Yeang HY (2002) Pollen tube growth and fruit-set success in Hevea brasiliensis hand-pollination influenced by the choice of clone and female flower. Euphytica 123:1-8.

Olapade EO (1991) General and specific combining ability for latex yield in Hevea brasiliensis. Indian J Genet 51:1-5.

Olapade EO and Omokhafe KO (1990) Hand pollination of Hevea brasiliensis in Nigeria (1984-1990); comparison with open pollinated field data. J Rubb Res Inst Sri Lanka 70:27-34.

Omokhafe KO (2001) Preliminary investigation into tree dryness in Hevea brasiliensis by path analysis of tree dryness and latex parameters. Tropicultura 19:1-4.

Omokhafe KO and Nasiru I (2005) Genetic improvement of Hevea brasiliensis in Nigeria. In: Mathew NM, Jacob CK, Nair MGS, Thomas KK, Satisha GC, Srinivas P, Korah AC, et al. (eds) Proceedings of the International Natural Rubber Conference. Modern Graphics, Cochin, India, pp 13-17.

Priyadarshan PM and Clement-Demange A (2004) Breeding Hevea Rubber: Formal and molecular genetics. Advances in Genetics 52:51-115.

Singh RK and Chaudhary BD (1985) Biometrical Methods in Quantitative Genetics Analysis. Kalyani Publishers, New Delhi, $318 \mathrm{pp}$.

Tuy LM, Anh LHN and Hoa TTT (2005) Estimation of general combining ability for the 1987-1995 Hevea breeding program at the Rubber Research Institute of Vietnam. In: Mathew NM, Jacob CK, Nair MGS, Thomas KK, Satisha GC, Srinivas P, Korah AC, et al. (eds) Proceedings of the International Natural Rubber Conference. Modern Graphics, Cochin, pp 36-42.

Associate Editor: Ernesto Paterniani 